\title{
AKOMODASI BUDAYA LOKAL DALAM LEGISLASI BIDANG HUKUM KELUARGA (HUKUM TENTANG HAK DAN KEWAJIBAN DALAM RUMAH TANGGA)
}

\author{
Yusmita \\ Fakultas Syariah IAIN Bengkulu \\ Jl. Raden Fatah Pagar Dewa Bengkulu \\ Email: yusmitag@gmail.com
}

\begin{abstract}
This article would like to point out that some rules about family law in Indonesia are heavily influenced by the growing local culture in society. Evident from the provisions of the Marriage Act no. 1 of 1974 and the Compilation of Islamic Law is quite much influenced by the culture and conditions that developed in Indonesia and the progress of the times. This is evident from the desire to get out of the classical Jurisdiction of figh that puts too much of a man in a very high position, and women in disadvantaged positions. For example, the article that regulates the balance of the rights and the position of husband and wife in the household, in the association in society, and in doing legal action. The influence of local culture that is already rooted in the community appears in the statement that the husband is the head of the household and the wife is a housewife. This implies an imbalance in the position of the husband and wife, this is clearly influenced by the local culture and is supported by religious doctrine that is already integral with society, which states men are leaders for women.
\end{abstract}

Keywords: local culture, family law, rights and obligations

\begin{abstract}
Abstrak: Artikel ini ingin menunjukkan bahwa beberapa aturan tentang hukum keluarga di Indonesia banyak dipengaruhi oleh budaya lokal yang berkembang di masyarakat. Terbukti dari pasal-pasal di dalam Undang-Undang Perkawinan No. 1 tahun 1974 dan Kompilasi Hukum Islam yang cukup banyak dipengaruhi oleh budaya dan kondisi yang berkembang di Indonesia serta kemajuan zaman. Ini tampak dari keinginan untuk keluar dari kungkungan fikih klasik yang terlalu memposisikan laki-laki pada posisi yang sangat tinggi, dan wanita pada posisi yang kurang diuntungkan. Sebagai contoh pasal yang mengatur tentang keseimbangan hak dan kedudukan suami isteri dalam rumah tangga, dalam pergaulan di masyarakat, dan dalam melakukan perbuatan hukum. Pengaruh budaya lokal yang sudah mengakar di masyarakat tampak pada pernyataan bahwa suami adalah kepala rumah tangga dan istri adalah ibu rumah tangga. Ini menunjukkan ketidak seimbangan kedudukan suami dan isteri, hal ini jelas dipengaruhi oleh budaya lokal dan didukung oleh doktrin agama yang sudah menyatu dengan masyarakat, yang menyatakan laki-laki adalah pemimpin bagi wanita.
\end{abstract}

Kata kunci: budaya lokal, hukum keluarga, hak dan kewajiban

\section{Pendahuluan}

Para ulama telah sepakat bahwa seluruh permasalahan yang timbul dan dialami oleh umat manusia, hukumnya telah digariskan dalam syari'at Islam. Hukum- hukum tersebut, sebagian dapat diketahui melalui nash, baik Alquran maupun hadis, sedangkan yang lainnya dapat diketahui melalui dalil-dalil yang tidak, secara langsung bersumber pada nash, seperti ijma', qiyas, istihsan, mashalih mursalah, 'urf, istishab dan berdasarkan syari'at orang-orang sebelum di- utusnya Nabi Muhammad saw. Seluruh hukum Islam yang diketahui, baik melalui nash maupun jalan lain tersebut, dinamakan dengan fiqih Islam. Bila suatu masalah muncul dan telah ditentukan hukumnya oleh nash, maka umat Islam wajib mengikuti petunjuk tersebut. Tetapi apabila dalam nash tidak disebutkan hukumnya secara qath'i, maka para mujtahid mempunyai kewajiban untuk menentukan hukumnya berdasarkan pertimbangan-pertimbangan tertentu, di antaranya pertimbangan 'urf dan adat kebiasaan masyarakat. 
Lingkungan dan kehidupan sosial kini merupakan suatu kenyataan yang ikut mempengaruhi kegiatan pelaksanaan ajaran agama. Hukum yang ditetapkan oleh para ulama tempo dulu, hanya merupakan jawaban atas realitas kehidupan yang ada pada masa itu. Agar selalu eksis, hukum Islam dituntut untuk menyesuaikan dirinya dengan lingkungan serta problema hidup yang sedang dihadapi oleh umat manusia. Sedangkan sesuatu yang dikatakan cocok dengan satu lingkungan belum tentu sesuai dengan lingkungan lainnya. Dengan demikian, lingkungan budaya lokal menjadi sangat penting untuk diperhatikan oleh para pembuat undang-undang ketika mereka akan menetapkan hukum, khususnya hukum Islam yang menjadi hukum positif.

Kasus Imam Syafi'i agaknya dapat dijadikan contoh nyata betapa ulama dahulu juga sangat mempertimbangkan masalah 'urf ini. Ketika berada di Mesir, Imam Syafi'i merubah sebagian keputusan hukumnya yang telah ditetapkan di Baghdad. Hal ini lantaran ia melihat adat di Mesir sangat berbeda dengan adat di Baghdad. Sehingga ia mempunyai dua madzhab yakni qaul qadim dan qaul jahid. Syari' at Islam mengakui keberadaan 'urf dalam penetapan hukum. Karena itu di Indonesia seyogianya juga harus mempertimbangkan urf dari masyarakat Indonesia dalam pembuatan aturan. Sehingga peraturan dan isi dari undang-undang yang sudah tidak sesuai dengan kondisi masyarakat Indonesia seharusnya direvisi dan disesuaikan dengan kebutuhan masyarakat Indonesia. Pada makalah ini yang akan dilihat adalah pengaruh adat masyarakat Indonesia terhadap isi undang-undang no. 1 tahun 1974 dan Kompilasi Hukum Islam yang berhubungan dengan hak dan kewajiban suami isteri dalam perkawinan.

\section{Kedudukan 'Urf dan Adat dalam Pembentukan Hukum}

Secara etimologis, 'urf berasal dari bahasa Arab yaitu "arafa" yang berarti "mengetahui" ia merupakan lawan dari "ankara" yang berarti "tidak tahu". ${ }^{1}$ Dalam falsafat bahasa, tutur

\footnotetext{
${ }^{1}$ Mohammad Hashim Kamali, Principle Of Islamic Jurisprudence,
}

kata yang muncul merupakan simbol dari pengalaman mental yang direduksi dari interaksi sosial seseorang. Karena itu, jika ingin mengetahui suatu makna kata, penelusuran sosiologis terhadap pemakaian kata di mana ia tumbuh dan berkembang menjadi sangat perlu. ${ }^{2}$

Dari penggunaan terma ini dalam tutur kata bangsa Arab, Ibnu Manzur mendefinisikan 'urf sebagai segala bentuk anjuran syari'at yang mencakup seluruh kebaikan dan begitu juga larangan yang mencakup keburukan sifat-sifat yang ghalib (sesuatu yang telah dikenal/umum/ biasa) yang jika dilihat manusia, mereka tidak akan merasa asing terhadapnya. ${ }^{3}$

Ulama yang pertama sekali mendefinisikan 'urf secara konsepsional adalah Abdullah bin Ahmad al-Nasafi (w.710 H) dalam kitabnya al Mushtshafa, yang kemudian diikuti oleh ulama berikutnya. Sebagaimana dikutip oleh Abu sanah, 'urf menurut al-Nasafi adalah sesuatu yang telah melembaga dalam jiwa manusia dengan landasan rasional, dan akal sehat manusia dapat menerimanya. ${ }^{4}$

Menurut Abu Sanah sendiri, 'urf adalah suatu masalah yang telah biasa dan mentradisi dalam jiwa manusia dan benar-benar telah melembaga. Penetapan itu didasarkan kepada akal sehat manusia, sehingga orang yang memiliki naluri yang baik tidak menolaknya dalam kehidupan bermasyarakat. $^{5}$

Dari dua definisi di atas, penggambaran tentang kebiasaan masyarakat masih bersifat umum. Ulama Ushul Fiqh kontemporer (Abdul Wahhab Khallaf dan Wahbah Zuhaili misalnya), lebih terperinci dalam mendeskripsikan definisi mereka, walaupun intinya sama. Abdul Wahhab Khalaf mendefinisikan 'urf sebagai "sesuatu yang dikenal oleh khalayak ramai, di mana mereka

(Selangor: Darul Ehsan, Pelanduk Publications, 1995), h. 359.

2 E. Sumaryono, Hermeneutik, Sebuah Metode Filsafat, (Yogyakarta: Kanisius, 1993), h. 24-25

${ }^{3}$ Ibnu Manzur, Lisan al Arab, Dar al Mishriyyat, (Mesir: Dar al-Mishriyyat, t.th), Jilid XI, h. 144.

${ }^{4}$ Ahmad Fahmi Abu Sanah, Al 'Urf wa al-'Adat fi Ra'yi alFuqaha, (Mesir:Matba'ah al-Azhar, 1947), h. 8.

${ }^{5}$ Ahmad Fahmi Abu Sanah, Al 'Ur f wa al-'Adat..., h. 8 
terbiasa melakukannya, baik perbuatan ataupun perkataan $^{6}$

Wahbah Zuhaili memberikan definisi yang lebih rinci. Menurutnya 'urf adalah sesuatu yang telah menjadi kebiasaan manusia dan mentradisi di kalangan mereka dalam bentuk perbuatan yang muncul dalam interaksinya. Atau berupa lafaz yang penggunaannya telah dikenal di tengah masyarakat dengan makna tertentu, sekalipun terma itu tidak lazim dipakai dalam ilmu bahasa, tetapi masyarakat tidak asing ketika mendengarnya. 'Urf dalam pengertian ini sama dengan adat (kebiasaan sosial). Definisi ini mencakup 'urf amali dan 'urf qauli".?

Berdasarkan definisi yang dikemukakan oleh dua ulama ushul tersebut, dapat diketahui bahwa 'urf memiliki dua bentuk, yakni perkataan dan perbuatan. Kedua kategori ini manakala masih asing dan belum mapan dalam perkataan dan tingkah laku masyarakat, tidak dapat dikatakan 'urf. Di samping itu, kebiasaan tersebut harus didasarkan kepada rasionalitas manusia, artinya akal sehat manusia tidak ada yang menolaknya. Apabila kebiasaan tersebut didasarkan kepada hawa nafsu dan syahwat, itu bukan urf.

Sementara itu, adat (custom) berarti pengulangan (tikrar) yakni perbuatan yang dilakukan secara berulang-ulang, ini mencakup praktek-praktek yang dilakukan individu maupun kelompok. Oleh karena itu kebiasaan personal seseorang termasuk dalam kategori adat. ${ }^{8}$ Abu sanah mendefinisikan adat dengan sesuatu yang dilakukan secara berulang-ulang tanpa ada hubungan rasional. ${ }^{9}$

Definisi di atas menunjukkan bahwa apabila suatu perbuatan dilakukan secara berulangulang menurut hukum akal, tidak dinamakan adat. Definisi tersebut juga menunjukkan adat itu mencakup persoalan yang amat luas,

${ }^{6}$ Abdul Wahhab Khallaf, Mashadir al-Tasyrii fi Ma La Nassha, terj. Oleh Bahrun Abubakar dengan judul: Sumbersumber Hukum Islam, (Bandung: Risalah, 1998), h. 205.

7 Wahbah Zuhaili, Ushul al Fiqh al-Islamy, (Beirut: Darl alFikr, 1986), h. 828.

${ }^{8}$ Mohammad Hashim Kamali, Principle..., h. 359.

9 Ahmad Fahmi Abu Sanah, Al 'Ur fwa al-Adat..., h. 10. termasuk permasalahan pribadi, seperti kebiasaan seseorang dalam tidur, makan, dan mengkonsumsi jenis makanan tertentu, atau permasalahan yang menyangkut orang banyak. Adat juga bisa muncul karena sebab alami, seperti cepatnya seseorang menjadi dewasa (baligh) di daerah tropis, demikian juga cepatnya pohon berbuah diwilayah yang beriklim panas. Di samping itu, adat juga bisa muncul dari hawa nafsu dan kerusakan akhlak, seperti korupsi, sebagaimana adat juga bisa muncul dari kasuskasus tertentu, seperti perubahan budaya suatu daerah disebabkan pengaruh budaya asing.

Dengan demikian, terlihat adanya perbedaan antara adat dengan 'urf. 'Urf harus berlaku pada kebanyakan orang didaerah tertentu, bukan pada pribadi atau kelompok. 'Urf bukanlah kebiasaan alami sebagaimana yang berlaku dalam kebanyakan adat, tetapi muncul dari suatu pengalaman dan pemikiran, seperti kebiasaan mayoritas masyarakat pada daerah tertentu yang menetapkan bahwa untuk memenuhi keperluan rumah tangga pada suatu perkawinan biasa diambil dari mas kawin yang diberikan suami.

\section{Hak dan Kewajiban Suami Isteri dalam Hukum Adat Secara Umum}

Hukum adalah aturan-aturan normatif yang mengatur pola perilaku manusia. Hukum tidak tumbuh di ruang vakum, melainkan tumbuh dari kesadaran masyarakat yang membutuhkan adanya suatu aturan bersama. Oleh karena itu, hukum seharusnya berkembang sehingga dapat mengadopsi nilai-nilai yang tumbuh di masyarakat termasuk nilai-nilai adat tradisi dan agama. Yang dimaksudkan dengan kaidah Aladatu muhakkamah dalam teori hukum Islam. Artinya, tradisi atau adat istiadat suatu masyarakat dapat dijadikan hukum. ${ }^{10}$ Konsekuensinya, produk hukum harus dilihat sebagai produk zamannya yang sulit melepaskan diri dari berbagai pengaruh

10 Jalaluddin Al-suyuthi, Al-Asybah wa al-Nazhäir, h. 63. Lihat juga Siti Musdah mulia, Perempuan Dan Hukum, Menuju Hukum Perkawinan Yang Adil: Memberdayakan Perempuan Indonesia, (Jakarta: Yayasan obor Indonesia, 2008), h. 133 
yang melingkupi kelahirannya, baik pengaruh sosiokultural maupun pengaruh sosio-politis. Sebagai produk sosial dan kultural, bahkan juga produk politik yang bernuansa ideologi, hukum idealnya bersifat kontekstual. ${ }^{11}$

Upaya konkrit pembaharuan hukum keluarga di Indonesia dimulai kembali tahun 1960-an yang berujung dengan lahirnya undang-undang Nomor 1 Tahun 1974 tentang perkawinan. Undang-undang perkawinan ini merupakan undang-undang pertama di Indonesia yang mengatur soal perkawinan secara nasional. Sebelum itu, urusan perkawinan diatur melalui beragam hukum yaitu hukum adat bagi warga negara asli hukum Islam bagi warga Indonesia asli yang beragama Islam, ordonansi perkawinan Indonesia kristen bagi warga negara Indonesia yang beragama Kristen di Jawa Minahasa dan Ambon. Kitab undang-undang hukum perdata bagi warga Indonesia keturunan Eropa dan Cina dan peraturan perkawinan campuran bagi perkawinan campuran. ${ }^{12}$

Hak dan kewajiban suami isteri dilihat dari hukum adat, dapat dianalisa bahwa hukum adat hanya berlaku di daerah yang sangat kental akan adat budayanya. Dan tidak dapat dipakai di adat lainnya, jadi hukum adat adalah hukum yang diwariskan turun temurun dari nenek moyang. Adapun contoh perkawinan dalam hukum adat adalah perkawinan semanda, perkawinan bebas, perkawinan belarian dan yang lainnya.

Mayoritas perumusan tentang hak dak kewajiban suami istri merupakan produk para fuqaha, di mana mereka dalam menetapkannya tidak terlepas dari budaya lokal tempat mereka menetapkan hukum. Pendapat para fuqaha itu juga dipengaruhi oleh kondisi dan waktu mereka menetapkan hukum. Dengan kata lain berubahnya zaman, tempat dan kondisi sosial masyarakat dapat merubah produk hukum. Demikian juga di Indonesia tentang hak dan kewajiban suami isteri ini diatur khusus di

${ }^{11}$ Siti Musdah Mulia, Perempuan dan Hukum..., h. 133.

12 Wirjono Prodjodikoro, Perkawinan di Indonesia, (Bandung: Vorkink Van hoeve, t.th), h. 77 dalam perundang-undangan.

Dalam hal hak dan kewajiban dalam perkawinan dengan hukum adat ini, dimungkinkan ketidakseimbangan dalam pemenuhannya. Contoh yang riel adalah seorang isteri yang hanya disuruh menunggu ladang dan pemenuhan atas haknya sama sekali tidak diperhatikan, terjadi di Lampung . Mengapa isteri diperlakukan seperti itu?, karena dalam adat suku Lampung asli, wanita itu dibeli untuk dijadikan isteri, sehingga terkesan setelah menjadi isteri wanita itu bisa diperlakukan semau suami. Apalagi jika si isteri tersebut tidak membawa "sesan" (serah-serahan), mka akan semakin parah diperlakukan seenaknya oleh suaminya.

Namun hukum adat dewasa ini kebanyakan sudah berkembang dan menyesuaikan diri dengan keadaan zaman. Ia tidak melarang lagi wanita bebas keluar rumah, baik suami maupun isteri berhak untuk melakukan perbuatan hukum. ${ }^{13}$

\section{Akomodasi Budaya lokal dalam Aturan Hak dan Kewajiban Suami Isteri dalam UU No.1/1974 Dan KHI}

Sebelum Indonesia merdeka, sudah ada hukum tertulis tentang perkawinan bagi golongangolongan tertentu. Yang menjadi masalah waktu itu adalah bagi warga bumiputra yang beragama Islam. Bagi mereka tidak ada aturan sendiri yang mengatur tentang perkawinan, tidak ada undangundang tersendiri yang dapat dijadikan patokan dalam pelaksanaan akad nikah perkawinannya. Bagi mereka selama itu berlaku hukum Islam yang sudah diresipilir dalam hukum adat berdasarkan teori recepsi yang dikemukakan oleh Hurgronye, Van Vollen Hoven, Ter Harr dan murid-muridnya. Tuntutan beberapa organisasi wanita di masa itu cukup memberikan gambaran bahwa usaha memiliki Undang-undang Perkawinan sudah diusahakan sejak Indonesia belum merdeka. Hal ini dapat dibuktikan pula bahwa persoalan tersebut pernah dibicarakan

\footnotetext{
${ }^{13}$ Hilman Hadikusuma, Hukum Perkawinan Indonesia, (Bandung: Mandar Maju, 2007), h. 105
} 
di Volksraad dalam rangka memenuhi tuntutan beberapa organisasi pada masa tersebut. ${ }^{14}$

Dalam UU no 1 tahun 1974, yakni undangundang perkawinan nasional mengatur tentang hak dan kewajiban suami isteri pada bab IV ayat 30 sampai 34. Pasal 30 disebutkan bahwa suami isteri memikul kewajiban yang luhur untuk menegakkan rumah tangga yang menjadi sendi dasar dari susunan masyarakat.

Menurut hukum adat pada umumnya yang berlaku dalam masyarakat bangsa Indonesia, baik dalam masyarakat kekerabatan bilateral maupun unilateral (patrilineal dan matrilineal) ataupun yang beralih-alih (altemerend), kewajiban untuk menegakkan keluarga/rumah tangga (suami isteri) bukan semata-mata menjadi kewajiban dan tanggung jawab dari suami isteri itu sendiri. Masih ada tanggung jawab dan dan kewajiban moral orang tua dan kerabat, walaupun sifatnya immaterial dan tidak langsung berupa perhatian dan pengawasan. Apalagi jika yang ditegakkan itu keluarga/rumah tangga yang masih baru dengan suami isteri yang berumur muda. ${ }^{15}$

Pasal 31 (1) Hak dan kedudukan suami isteri adalah seimbang dengan hak dan kedudukan suami dalam kehidupan rumah tangga dan pergaulan hidup bersama dalam masyarakat. (2) Masing-masing pihak mempunyai hak untuk melakukan perbuatan hukum. (3) suami adalah kepala rumah tangga dan isteri adalah ibu rumah tangga.

Di dalam Kompilasi Hukum Islam hal ini diatur di dalam Pasal 78 suami istri harus mempunyai tempat kediaman yang tetap. Rumah kediaman yang dimaksud dalam ayat (1), ditentukan oleh suami istri bersama. Pasal 79 suami adalah kepala keluarga dan istri ibu rumah tangga. Hak dan kedudukan istri adalah seimbang dengan hak dan kedudukan suami dalam kehidupan rumah tangga dan pergaulan hidup bersama dalam masyarakat. Masing-masing pihak berhak untuk melakukan

\footnotetext{
${ }^{14}$ Abdul Manan, Aneka Masalah Hukum Perdata Islam di Indonesia, (Jakarta: Kencana Media Group, 2008), h. 3.

${ }^{15}$ Hilman Hadikusuma, Hukum Perkawinan ... , h. 104
}

perbuatan hukum. ${ }^{16}$

Pasal di atas terlihat satu segi adanya keseimbangan antara kedudukan suami dan isteri di dalam kehidupan berumah tangga, masyarakat dan hak melakukan perbuatan hukum. Tapi di sisi lain, terlihat ketidak seimbangan kedudukan antara suami dan isteri. Suami dinyatakan sebagai kepala rumah tangga sementara isteri hanya ibu rumah tangga. Jika keseimbangan yang diinginkan seharusnya suami adalah bapak rumah tangga, isteri adalah ibu rumah tangga. Hal ini jelas dipengaruhi oleh adat dan budaya yang belum bisa lepas dari masyarakat Indonesia.

Hukum adat dewasa ini kebanyakan sudah menyesuaikan diri dengan keadaan zaman, ia tidak melarang lagi wanita bebas keluar rumah, baik isteri maupun suami masing-masing berhak melakukan perbuatan hukum. Isteri bebas berbelanja ke pasar, isteri bebas melakukan jual beli, berdagang keliling, menunggu kedai, bekerja di kantor, menjadi guru, menjadi kepala desa, bahkan menjadi angkatan bersenjata. Tetapi dalam hal tertentu yang menyangkut adat, mengenai harta kekayaan adat, bangunan adat, tanak kerabat, tanah adat, kedudukan adat, isteri tidak berhak melakukan perbuatan sendiri tanpa persetujuan suami, tanpa persetujuan kerabat. Tanah pusaka di Minangkabau atau tanah kerabat di Lampung hanya wewenang lelaki untuk membuat transaksinya. Di minangkabau kedudukan penghulu tidak dipegang wanita, di Lampung tidak ada wanita yang berkedudukan sebagai sebatin atau punyimbang. ${ }^{17}$

Di samping itu, ketidak seimbangan antara suami dan isteri di dalam rumah tangga pada hukum positif dan realita di masyarakat juga tidak terlepas dari bentuk perkawinan yang terjadi, seperti bentuk perkawinan jujur, perkawinan semenda, perkawinan bebas, perkawinan pologami, perkawinan ganti tikar (levirat), perkawinan turun ranjang (sororat), perkawinan belarian, perkawinan memeruskan

\footnotetext{
${ }^{16}$ Abdurrahman, Kompilasi Hukum Islam di Indonesia, (Jakarta: Akademika Pressindo, 2005), h. 132

${ }^{17}$ Hilman Hadikusuma, Hukum Perkawinan..., h. 105.
} 
dan (keturunan), perkawinan memasukkan (dalam kerabat), dan sebagainya. Bentuk-bentuk perkawinan tersebut besar pengaruhnya bagi kedudukan suami dan isteri tidak seimbang ${ }^{18}$

Bentuk perkawianan adat lain yang menunjukkan ketidak seimbangan kedudukan antara suami dan isteri adalah bentuk perkawinan dengan pembayaran jujur yang mempertahankan keturunan menurut garis lelaki, di mana isteri setelah perkawinan masuk dalam kerabat suami, maka hak dan kewajiban suami dan isteri berbeda. Hak dan kedudukan isteri lebih rendah dari hak dan kedudukan suami. Isteri harus tunduk dan patuh kepada suami dan kerabatnya, segala sesuatu diselesaikan dengan musyawarak kerabatnya. Isteri hanya pendamping suami, membantu suami dalam mengatur kehidupan rumah tangga dan hubungan kekerabatan atau dalam pergaulan masyarakat (adat). ${ }^{19}$

Pasal 33 UU Perkawinan/1974 yakni suami dan isteri wajib saling cinta mencintai, hormat menghormati, setia dan memberi bantuan lahir batin yang satu kepada yang lain. Pasal 34 (1) Suami wajib melindungi istrinya, dan memberikan segala sesuatu keperluan hidup berumah tangga sesuai dengan kemampuannya. (2) Isteri wajib mengatur rumah tangga sebaikbaiknya. (3) Jika suami isteri melalaikan kewajibannya, masing-masing dapat mengajukan gugatan kepada pengadilan.

Sementara pada Kompilasi Hukum Islam, pasal 77 suami istri memikul kewajiban yang luhur untuk menegakkan rumah tangga yang sakinah, mawaddah dan rahmah yang menjadi sendi dasar dari susunan masyarakat. Suami istri wajib saling cinta mencintai, hormat menghormati, setia dan memberi bantuan lahir batin yang satu kepada yang lain. Suami istri memikul kewajiban untuk mengasuh dan memelihara anak-anak mereka, baik mengenai pertumbuhan jasmani, rohani maupun kecerdasannya dna pendidikan agamnya. Suami istri wajib memelihara kehormatannya. Jika suami atau istri melalaikan kewajibannya, masing-

\footnotetext{
${ }^{18}$ Hilman Hadikusuma, Hukum Perkawinan..., h. 104.

${ }^{19}$ Hilman Hadikusuma, Hukum Perkawinan..., h. 104-105.
}

masing dapat mengajukan guguatan kepada Pengadilan Agama. ${ }^{20}$

Pasal 80 KHI Suami adalah pembimbing terhadap istri dan rumah tangganya, akan tetapi mengenai hal-hal urusan rumah tangga yang penting-penting diputuskan oleh suami istri bersama. Suami wajib melindungi istrinya dan memberikan segala sesuatu keperluan hidup berumah tangga sesuai dengan kemampuannya. Suami wajib memberi pendidikan agam kepada istrinya dan memberi kesempatan belajar pengetahuan yang berguna dan bermanfaat bagi agama, dan bangsa. Sesuai dengan penghasilannya suami menanggung: (a) nafkah, kiswah dan tempat kediaman bagi istri, (b) biaya rumah tangga, biaya perawatan dan biaya pengobatan bagi istri dan anak, (c) biaya pendidikan bagi anak. Kewajiban suami terhadap istrinya seperti tersebut pada ayat (a) huruf a dan b di atas mulai berlaku sesudah ada tamkin sempurna dari istrinya. Istri dapat membebaskan suaminya dari kewajiban terhadap dirinya sebagaimana tersebut pada ayat (4) huruf a dan b. Kewajiban suami sebagaimana dimaksud ayat (2) gugur apabila istri nusyuz. ${ }^{21}$

Pasal 82 suami yang mempunyai istri lebih dari seorang berkewajiban memberi tempat tinggal dan biaya hidup kepada masing-masing istri secara berimbang menurut besar kecilnya keluarga yang ditanggung masing-masing istri, kecuali jika ada perjanjian perkawinan. Dalam hal para istri rela dan ikhlas, suami dapat menempatkan istrinya dalam satu tempat kediaman. ${ }^{22}$

Pasal 31 Undang-undang perkawinan tahun 1974 ayat (1) Hak dan kedudukan suami isteri adalah seimbang dengan hak dan kedudukan suami dalam kehidupan rumah tangga dan pergaulan hidup bersama dalam masyarakat.(2) Masing-masing pihak mempunyai hak untuk melakukan perbuatan hukum. Pasal di atas sejalan dengan pasal 79 ayat 2 dan 3 KHI. Kalau kita cermati pasal di atas dan waktu keluarnya

\footnotetext{
${ }^{20}$ Abdurrahman, Kompilasi Hukum..., h. 132.

${ }^{21}$ Abdurrahman, Kompilasi Hukum..., h. 132-133.

${ }^{22}$ Abdurrahman, Kompilasi Hukum..., h. 134.
} 
undang-undang ini di mana gerakan umat Islam yang tergabung di dalam ormas-ormas Islam, aktifis dan organisasi-organisasi perempuan menginginkan adanya aturan yang mengikat bagi umat Islam dalm bidang perkawinan. Mereka, terutama perempuan menginginkan adanya kesetaraan antara laki-laki dan perempuan dalam rumah tangga. Sebelumnya posisi perempuan dalam rumah tangga selalu di bawah kekuasaan laki-laki, maka budaya lokal ini coba digeser para aktifis perempuan menjadi budaya baru yaitu persamaan hak antara laki-laki dan perempuan.

Simposium ISWI (Ikatan sarjana Wanita Indonesia) tanggal 29 Januari 1972 memberi saran kepada pengurusnya agar memperjuangkan kembali Undang-undang Perkawinan untuk diberlakukan kepada seluruh warga negara Indonesia. Kemudian Badan Musyawarah Organisasi-organisasi Wanita Islam Indonesia pada tanggal 22 Februari 1972 juga mendesak pemerintah agar mengajukan kembali kedua RUU tentang Perkawinaan yang dahulu dikembalikan oleh DPR kepada pemerintah. Desakan ini juga dilakukan oleh Himpunan Mahasiswa Islam (HMI) dalam acara sarasehan pada tanggal 11 Februari 1973 di Jakarta. ${ }^{23}$

Pada saat munculnya undang-undang ini, kaum perempuan sudah mulai keluar dari kungkungan fiqh klasik, yang selalu memposisikan perempuan dalam kekuasaan suaminya. Karena pemahaman mereka terhadap ayat alQuran dalam surat al-Nisa' ayat 34:

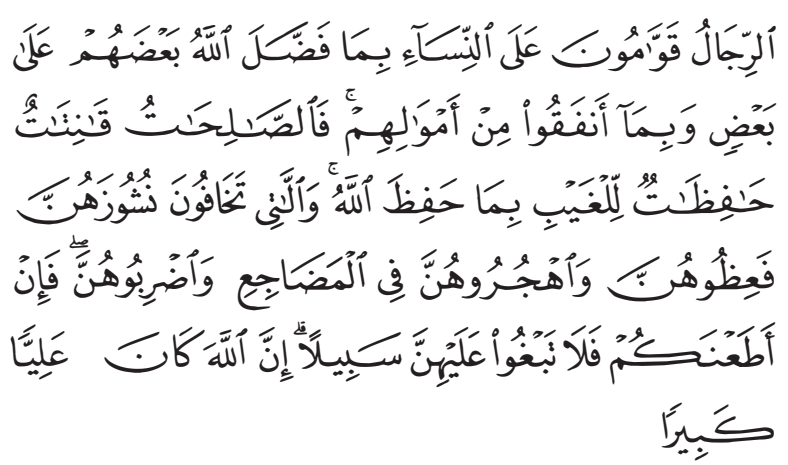

"Kaum laki-laki itu adalah pemimpin bagi kaum wanita, oleh karena Allah telah melebibkan sebahagian mereka (laki-laki) atas sebahagian yang

${ }^{23}$ Abdul Manan, Aneka Masalah..., h. 4. lain (wanita), dan karena mereka (laki-laki) telah menafkahkan sebagian dari harta mereka. sebab itu Maka wanita yang saleh, ialah yang taat kepada Allah lagi memelihara diri ketika suaminya tidak ada, oleh karena Allah telah memelihara (mereka). Wanita-wanita yang kamu khawatirkan nusyuznya, maka nasehatilah mereka dan pisahkanlah mereka di tempat tidur mereka, dan pukullah mereka. kemudian jika mereka mentaatimu, Maka janganlah kamu mencaricari jalan untuk menyusahkannya. Sesungguhnya Allah Maha Tinggi lagi Maha Besar".

Pemahaman masyarakat Indonesia juga sudah dipengaruhi oleh perkembangan hukum keluarga di negara-negara muslim lain, seperti Mesir, Suadi Arabia, Turki dan yang lainnya, yang sudah lebih dahulu menerobos keluar dari kungkungan fiqh klasik untuk mengengkat derajat kaum wanita. Walaupun belum seutuhnya keluar, minimal sudah berani menetapkan aturan baru yang berbeda dengan fiqh klasik. Ijtihad di kalangan ulama juga sudah mulai terbuka sehingga dapat memahami ajaran Islam secara konprehensip, karena ayat-ayat lain dan hadis lain banyak yang jarang dimunculkan dalam penganalisaan tentang hak dan kewajiban suami istri.

Kalau kita cermati ayat di atas juga mempunyai kontibusi yang besar terhadap pasal 31 ayat (3) suami adalah kepala rumah tangga dan isteri adalah ibu rumah tangga. Budaya lokal masyarakat Indonesia pada saat itu juga masih menganut paham bahwa laki-laki adalah penentu dan pemimpin dalam rumah tangganya. Pemikiran itu juga masih berlanjut sampai saat ini. Dengan demikian pasal ini benar-benar merupakan akomodasi budaya lokal masyarakat Indonesia yang berlaku dari dahulu sampai sekarang. Hal ini dipengaruhi oleh budaya patrelineal yang mayoritas dianut suku-suku di Indonesia, dan bagi yang beragama Islam diperkuat lagi dengan ajaran Islam klasik yang sangat patrilineal.

Kebanyakan dalam kejadian selama ini, ketidak terpenuhinya hak dan kewajiban antara suami dan isteri, dan lebih cenderung 
kepada isteri, mungkin dikarenakan kurangnya pemahaman dalam ayat maupun hadist tentang hak dan kewajiban suami isteri. Selain itu juga, kesalahan dalam pemahaman hadist nabi yang artinya: Nabi Muhammad saw pernah bersabda: "Jika aku boleh memerintahkan seseorang untuk menyembah yang lain, aku akan memerintabkan istri untuk menyembah suaminya." (HR. Bukhari dan Muslim)

Semuanya ditafsirkan hanya tekstual saja, padahal dalam ayat yang terkandung dalam ayat dan hadist tersebut memaknai adanya hak-hak isteri, seperti:

$$
\text { والرجل راع اهله وهو مسؤل عن رعيته }
$$

"Laki-laki menjadi pemimpin bagi keluarganya dan dia bertanggung jawab atas apa yang dipimpinnya" (HR Bukhari Muslim)

$$
\text { والمرأة راعية فن بيت زوجهاومسؤلة عن رعيتها }
$$

"Perempuan adalah pemimpin di dalam rumah tangga suaminya dan dia bertanggung jawab terhadap apa yang dipimpinnya" (HR. Bukhari).

Kebanyakan para ulama sebelumnya mengabaikan ayat-ayat lain yang menyatakan tentang keseimbangan antara laki-laki dan perempuan dan keharusan berbuat baik pada isteri.

Pasal 33 yakni suami dan isteri wajib saling cinta mencintai, hormat menghormati, setia dan memberi bantuan lahir batin yang satu kepada yang lain. Pengaruh adat istiadat pada kewajiban saling mencintai, hormat menghormati setia dan memberi bantuan lahir dan batin ini jika mereka masih terikat dengan hubungan kekerabatan, mereka juga harus mencintai, menghormati, saling bantu membantu dalam hubungan "dalihan na tolu" di tanah Batak. Dalam hubungan kemenakan dengan mamak, anak pisang dengan bako-bakinya di Minangkabau, denganadik wari, lebu kelama, menulung, di tanah Lampung. ${ }^{24}$

Pasal di atas juga dipengaruhi oleh keinginan umat Islam yang sudah mulai berusaha menciptakan budaya baru di tengah-tengah masya-

${ }^{24}$ Hilman hadikusuma, Hukum Perkawinan ..., h. 106. rakat, yang menginginkan adanya keseimbangan antara laki-laki dan perempuan. Kata "saling" pada pasal di atas sangat jelas menunjukkan keseimbangan. Budaya lokal yang ada pada saat ini adalah budaya keinginan keluar dari tradisi fiqh klasik yang memposisikan perempuan pada posisi nomor dua di dalam keluarga. Budaya lokal yang mempengaruhi ini juga merupakan budaya lokal di kalangan kaum terpelajar dan aktifis dan organisasi perempuan. Karena kalau dilapisan masyarakat bawah budaya fiqh klasik yang mempsosisikan perempuan berada di bawah laki-laki masih sangat dominan. Karena banyak ayat Alquran dan hadis yang tidak disyi'arkan kepada mereka. Padahal ayat Alquran menjelaskan dalam surat Al-Baqarah: 228
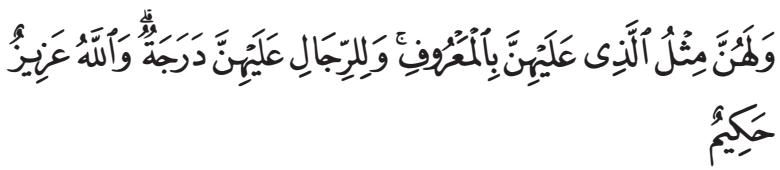

Para wanita mempunyai hak yang seimbang dengan kewajibannya menurut cara yang ma'ruf. Akan tetapi Para suami, mempunyai satu tingkatan kelebihan daripada isterinya. Dan Allah Maha Perkasa lagi Maha Bijaksana.

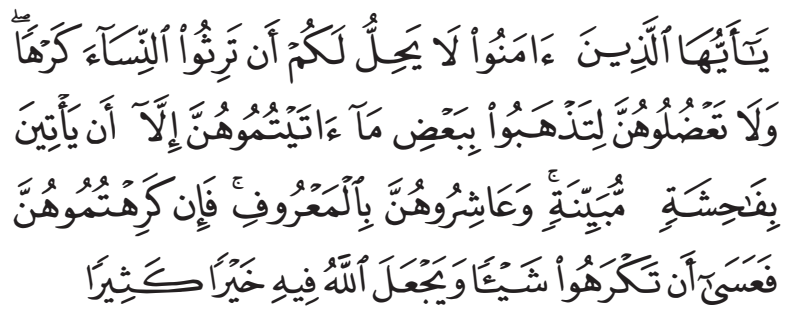

Hai orang-orang yang beriman, tidak halal bagi kamu mempusakai wanita dengan jalan paksa. Ddan janganlah kamu menyusahkan mereka karena hendak mengambil kembali sebagian dari apa yang telah kamu berikan kepadanya, terkecuali bila mereka melakukan pekerjaan keji yang nyata. Dan bergaullah dengan mereka secara patut. kemudian bila kamu tidak menyukai mereka, (maka bersabarlah) karena mungkin kamu tidak menyukai sesuatu, Padahal Allah menjadikan padanya kebaikan yang banyak.

Hadis Rasul menyatakan “ orang yang paling baik di antara kalian adalah orang yang paling baik memperlakukan keluarganya, dan aku adalah orang yang paling baik memperlakukan keluargaku”. Hadis lain "Orang mukmin yang 
paling sempurna keimanannya adalah orang yang paling baik akhlaknya di antara kalian. Dan orang yang paling baik di antara kalian adalah orang yang paling baik kepada isterinya”.

Pasal 34 (1) Suami wajib melindungi istrinya, dan memberikan segala sesuatu keperluan hidup berumah tangga sesuai dengan kemampuannya. (2) Isteri wajib mengatur rumah tangga sebaikbaiknya.

Ajaran Islam sangat berpengaruh terhadap pasal-pasal yang terdapat undang-undang no. 1/1974 dan KHI, hal ini karena ajaran Islam sudah menyatu dengan umat Islam, sehingga terkadang sulit membedakan antara budaya dan ajaran Islam. Pada daerah-daerah tertentu ajaran Islam menjadi budaya lokal yang tidak bisa dipisahakn terlebih lagi ajaran Islam yang dipahami ulama klasik sangat fatrilineal yang sesuai dengan mayoritas budaya lokal masyarakat Indonesia. Karena itu pasal 34 UUP No. 1/1974 di atas benar-benar dipengaruhi budaya lokal, yang membebankan kepada suami bertanggung jawab terhadap nafkah keluarga dan bertanggung jawab untuk melindungi keluarganya.

Isteri karena pemahaman masyarakat pada posisi ibu rumah tangga, yang sesuai dengan pasal 31 ayat (3), sebagai ibu rumah tangga, maka ia berkewajiban mengatur rumah tangga sebaikbaiknya. Ia berkewajiban serta bertanggung jawab terhadap penggunaan fasilitas untuk kelangsungan hidup keluarga itu. Ia wajib mengatur dan menata penggunaan kekayaan materi tado, untuk kepentingan kehidupan rumag tangga, kewajiban untuk mengurus suami dan (bila ada) anak-anak. Gambaran di atas menunjukkan kedudukan isteri sebagai ibu rumah tangga. ${ }^{25}$

Jelas sekali pasal ini dipengaruhi oleh pemahaman msayrakat, khususnya umat Islam pada saat keluarnya undang-undang ini. Walaupun pada kenyataannya itu hanya pada tatanan pemahaman, karena kalau kita lihat secara menyeluruh di Indonesia pada saat itu wanita-

\footnotetext{
${ }^{25}$ Soerjono Soekanto, Hukum Adat Indonesia, (Jakarta: Raja Grafindo Persada, 2013), h. 244.
}

wanita sudah sangat banyak bekerja, terutama ke ladang untuk memenuhi kebutuhan keluarganya.

Pasal 34 ayat (3) Jika suami isteri melalaikan kewajibannya, masing-masing dapat mengajukan gugatan kepada pengadilan. Klausula ini membuka pintu bagi mereka yang akan mempergunakannya. Jika masalah yang menjadi perselisihan tidak lagi dapat diatasi secara kekeluargaan. ${ }^{26}$

Ini menunjukkan bahwa kesadaran hukum masyarakat ketika aturan ini diundangkan sudah baik, sehingga apapun kejadian hukum yang berhubungan dengan rumah tangga harus memiliki kekuatan hukum yang tetap. Pasal ini juga menunjukkan keinginan masyarakat untuk memposisikan antara suami dan istri memiliki hak yang sama dalam mengambil keputusan untuk membubarkan perkawinan apabila ada hak masing-masing tidak terpenuhi. Dengan adanya aturan ini keinginan memposisikan wanita sebagai manusia yang dapat menentukan jalan hidupnya baik di masyarakat maupun di dalam keluarga dapat diakomodir. Di samping itu, tersurat keseimbangan hak dan kewajiban suami istri itu seimbang dan sederajat.

\section{Penutup}

Dari uraian di atas, dapat disimpulkan bahwa pasal-pasal di dalam undang-undang perkawinan no. 1 tahun 1974 dan Kompilasi Hukum Islam banyak dipengaruhi oleh budaya dan kondisi yang berkembang di Indonesia, terutama keinginan untuk keluar dari kungkungan fiqh klasik yang terlalu memposisikan laki-laki pada posisi yang sangat tinggi, dan wanita pada posisi yang kurang diuntungkan. Sebagian pasal-pasal tersebut dipengaruhi oleh budaya dan cara berpikir yang sudah mengikuti perkembanagn zaman, seperti pasal yang mengatur tentang keseimbangan hak dan kedudukan suami isteri dalam rumah tangga, dalam pergaulan di masyarakat dan dalam melakukan perbuatan

\footnotetext{
${ }^{26}$ Hilman Hadikusuma, Hukum Perkawinan..., h. 106.
} 
hukum serta suami dan isteri wajib saling cinta mencintai, hormat menghormati, setia dan memberi bantuan lahir batin yang satu kepada yang lain.

Sebagian lain dipengaruhi oleh budaya lokal yang sudah mengakar dimasyarakat seperti pernyataan suami adalah kepala rumah tangga dan istri adalah ibu rumah tangga. Ini menunjukkan ketidak seimbangan kedudukan suami dan isteri, hal ini dipengaruhi oleh budaya lokal dan bentuk pernikahan yang memposisikan kedudukan isteri lebih rendah dari suami, dan ini juga didukung oleh doktrin agama yang sudah menyatu dengan masyarakat, yang menyakan laki-laki adalah pemimpin bagi wanita.

Adapun aturan jika suami isteri melalaikan kewajibannya, masing-masing dapat mengajukan gugatan kepada pengadilan. Ini dipengaruhi oleh kesadaran hukum yang sudah timbul di tengahtengah masyarakat tentang suatu perbuatan hukum harus mempunyai kekauatan hukum yang dilindungi oleh negara. Dengan demikian jelaslah bahwa sebuah perundang-undangan selalu dipengaruhi oleh budaya lokal dan kondisis yang sedang berkembang di tengah-tengah masyarakat yang menginginkan hak dan kewajiban suami istri seimbang dan sederajat.

\section{Pustaka Acuan}

Abdurrahman, Kompilasi Hukum Islam Di Indonesia, Jakarta: Akademika Pressindo, 2005.

Alhamdani, HSA, Risalah Nikah, Jakarta: Pustaka Amani, 1989.

Hadikusuma, Hilman, Hukum Perkawinan Indonesia, Bandung: Mandar Maju, 2007.
Khallaf, Abdul Wahhab, Mashadir al-Tasyrii $f i$ Ma La Nassha, terj. Oleh Bahrun Abubakar dengan judul Sumber-Sumber Hukum Islam, Bandung: Risalah, 1984.

Manan, Abdul, Aneka Masalah Hukum Perdata Islam di Indonesia, Jakarta: Kencana Media Group, 2008.

Manzur, Ibnu , Lisan al-Arab, Mesir: Dar alMishriyyat, t.th., Jilid XI

Mohammad Hashim Kamali, Principle of Islamic Jurisprudence, Selangor, Darul Ehsan, Pelanduk Publications, 1995

Mulia, Siti Musdah, Perempuan Dan Hukum, Menuju Hukum Perkawinan Yang Adil: Memberdayakan Perempuan Indonesia, Yayasan Obor Indonesia, Jakarta, 2008

Prodjodikoro, Wirjono, Perkawinan di Indonesia, Bandung: Vorkink Van hoeve, t.th.

Sabiq, Sayyid, Fikih Sunnah 7, Bandung: PT.AlMa'arif, 2007.

Sanah, Ahmad Fahmi Abu, al 'Urf wa al Adat Fi Ra'yi al Fuqaha, Mesir: Matbaah al-Azhar, 1947.

Soekanto, Soerjono, Hukum Adat Indonesia, Jakarta, Raja Grafindo Persada, 2013.

Sumaryono, E., Hermeneutik, Sebuah Metode Filsafat, Yogyakarta: Kanisius, 1993.

Suyuthi, Jalaluddin al-, Al-Asybah wa alNazhair, t,tp.

Zuhaili, Wahbah al-, Figh Islam Wa Adillatuhu, Damaskus: Gema Insani \& Darul Fikri, 2007.

Zuhaili, Wahbah al-, Ushul al Figh al Islamy, Beirut: Darl al-Fikr, 1986. 